\title{
Does the minimum wage reduce wage inequality? Evidence from Thailand
}

\author{
Attakrit Leckcivilize
}

\section{Correspondence:}

leckcivilize@aoek.uni-hannover.de Institute of Labour Economics, Leibniz University of Hannover, Königsworther Platz 1, 30167 Hannover, Germany

\section{黛 Springer}

\begin{abstract}
Most of the minimum wage literature in developing countries provides supporting evidence of its effectiveness in reducing wage inequality. Using minimum wage data from Thailand (1985-2010), I find rather mixed outcomes. The minimum wage seems to help compress the lower part of wage distribution for employees in large businesses. However, the effect does not extend to small and medium firms in the covered sector. In contrast with its role as a benchmark for wage adjustment in Latin America, the minimum wage in Thailand does not reduce overall wage inequality owing to the high non-compliance rate and weak law enforcement, particularly in the informal sector.
\end{abstract}

JEL classification: J38; O17

Keywords: Minimum wage; Thailand; Wage inequality; Formal and informal sector; Compliance

\section{Introduction}

The effects of minimum wages on various groups of workers have been a popular subject of vigorous debate in the long history of economic literature, as reviewed by Brown (1999); Card and Krueger (1995); Machin and Manning (1997); and Neumark and Wascher (2008). A few of the reasons for the minimum wage policy are its potential to reduce wage inequality, especially among low-paid workers, and its potential to lift these workers and their families out of poverty (Saget 2001). Therefore, it is crucial to verify any effects minimum wages have on wage distributions. Research from the US, UK and Canada in the 1990s (Card and Krueger 1994; DiNardo et al. 1996; Fortin and Lemieux 2000; Lee 1999; Machin and Manning 1994) found that minimum wages significantly reduce wage dispersion. Recent studies in these countries find smaller direct and spillover effects of the minimum wage on the overall wage distribution because minimum wages were set at the level where only a small fraction of workers were directly affected (Autor et al. 2010; Dickens and Manning 2004). Hence, it is interesting to investigate the impacts of such policies in the context of developing countries where minimum wages tend to affect a larger fraction of workers.

However, the compliance with the minimum wage law in developing countries is far from perfect and a significant proportion of workers are in the informal sector. So the expected result is rather ambiguous. Moreover, comparisons across studies in developing countries are more complicated due to differences in minimum wage levels, enforcement and labor market institutions (Lemos 2009). Though these studies mostly agree on the

(c) 2015 Leckcivilize. Open Access This article is distributed under the terms of the Creative Commons Attribution 4.0 International License (http://creativecommons.org/licenses/by/4.0/), which permits unrestricted use, distribution, and reproduction in any medium, provided you give appropriate credit to the original author(s) and the source, provide a link to the Creative Commons license, and indicate if changes were made. 
positive wage compression effect of minimum wages in the formal sector, the results in the informal sector are rather mixed (see Maloney and Mendez 2003; Neumark and Wascher 2008, for a literature survey).

There are several reasons that the minimum wage can affect the informal wage distribution in spite of its expected ineffectiveness for informal workers. First, the minimum wage could induce the relocation of capital from the formal sector to the labor intensive informal sector, leading to higher informal sector wages (Harrison and Leamer 1997). Maloney and Mendez (2003) also argue that the minimum wage could act as a benchmark for "fair" remuneration (the so-called 'lighthouse effect'). Moreover, Khamis (2013) provides evidence from Argentina that employers might comply with the minimum wage law but not other benefit entitlements such as social security contribution (which is widely used to classify workers into the formal or informal sector). In addition, Boeri et al. (2010) use the matching model to show that if the introduction of the minimum wage changes the skill composition between formal and informal sectors, such sorting of workers by skill could lead to higher average skills of workers in the informal sector, thus, higher average wages.

Most studies in Latin America and the Caribbean report positive wage compression effects of the minimum wage in both sectors (with a few exceptions such as Honduras in Gindling and Terrell 2009). For example, Freeman and Freeman (1992) observe spikes around the minimum wage in the earning distribution of all Puerto Rican workers whereas Lemos (2009) finds that the minimum wage in Brazil compresses the wage distribution of not only the formal and informal sectors but also low-educated workers and the self-employed. Using kernel-density plots, Maloney et al. (2001) show that minimum wages could influence the distribution of wages in both the formal and informal sectors of eight Latin American countries with stronger distortion around the minimum wages in the informal wage distribution in Brazil, Mexico, Argentina and Uruguay. In case of the Mexico, Bosch and Manacorda (2010) employ a modified version of the Lee (1999) model and conclude that the minimum wage policy compresses the bottom part of Mexico's wage distribution with more pronounced effects in the informal sector (up to the eighth decile of the informal wage distribution). They also observe a positive correlation between minimum wages and inequality of sub-minimum wage workers and stronger spillover effects in the informal sector.

Outside Latin America and the Caribbean, studies on the effects of minimum wages on wage inequality in other developing countries are less common (for a review of evidence from developing countries in other regions, see Saget 2001). Despite rising or persistent wage and income inequality in East and Southeast Asian economies, there is a paucity of evidence of the minimum wage effects on the wage distribution in this region. The existing literature focuses on economic liberation or Foreign Direct Investment (FDI) as the underlying factor of such trends in inequality (Jomo 2006; Te Velde and Morrissey 2004). The only exception is Indonesia where researchers find conflicting results. Particularly, Rama (2001) and Suryahadi et al. (2001) show that minimum wage hikes have a positive impact on average wages of all workers and all segments of the workforce but are mostly insignificant except for the sub-sample of blue-collar workers. On the contrary, using the simulation framework, Bird and Manning (2008) report negative effects of the policy on wages in the informal sector.

With respect to wage inequality in Thailand, similar to the Anglo-Saxon economies, Lathapipat (2009) finds evidence for wage polarization in Thailand during the late 1980s 
to early 2000s (Table 4.1 in Lathapipat (2008) and Figure five in Lathapipat (2009)). Wage inequality at the top had risen whereas wage gaps between the median and the first decile were narrowed down. Lathapipat proposes that the rise of the bottom part of the wage distribution could result from an internal migration of laborers from hidden unemployment in rural areas to the modern sector in urban areas. Yet it is interesting to investigate if other factors such as labor market institutions contribute to such a finding.

The objective of this paper is to assess the role of the minimum wage policy in narrowing the wage gap of low-paid workers in Thailand. Additionally, it contributes to the small literature on the differential effects of the minimum wage on formal and informal wage inequality in Southeast Asia. This paper uses the Thai Labor Force Survey (LFS) in the first and third quarters (dry and rainy seasons) from 1985 to 2010. It exploits variation in the 'effective minimum', which is defined as the difference between the statutory minimum wage and median wage in each province (Lee 1999), to identify impacts of the minimum wage on different percentiles of wages in that province. However, Lee's econometric specifications are subjected to criticisms on omitted variables and division biases. To circumvent such problems, this paper follows the methodology proposed by Autor et al. (2010). Particularly, provincial fixed effects and provincial linear trends are included as well as the statutory minimum wage in each province-year is used as an instrumental variable for the effective minimum.

The results show no discernible wage compression effect on the overall labor market and in sectors obligated to pay the minimum wage (the so-called 'covered sector'). In other words, the minimum wage does not result in significant wage compression for either all employees or workers in the covered sector. However, the evidence suggests that the minimum wage significantly compresses the wage distribution of workers in large establishments in the covered sector. To verify whether such a finding is driven by periods of incremental rises in statutory minimum wage after the 1997 Asian financial crisis or not, this paper uses the methodology based on "Fraction of Affected Workers" by Card and Krueger (1995) to assess the effects of the minimum wage on the wage distribution of periods with significant hikes. Still, the main result is affirmed.

Thus, the finding of this paper highlights the role of a difference in the compliance rate between the formal and informal sectors on effectiveness of the minimum wage policy, provided that firm size can be used to classify workers into either the formal or informal sector. Although such finding is in contrast to most of the literature from Latin America, where minimum wages effectively influence both formal and informal wage distribution, it is in line with the segmented labor market (or two-sector) model.

The paper is structured as follows. Section 2 describes the minimum wage and its enforcement in Thailand. Then Section 3 presents data and descriptive statistics. Section 4 outlines the methodology while Section 5 briefly discusses the results. Section 6 presents some robustness checks and Section 7 discusses the results with respect to law enforcement and economic theories. The conclusion and discussion of future research are in Section 8.

\section{Minimum wage and its enforcement in Thailand}

The minimum wage was first introduced for private employees outside the agricultural sector in Bangkok and adjacent cities in April 1973. Later in October 1974, its coverage 
was expanded to the whole country. The statutory minimum wages have been set differently across zones as wages in baht per day - which, in general, is defined as eight hours of work. As for part-time workers, they are also entitled to receive an hourly minimum wage which is equal to the daily minimum wage divided by eight hours. ${ }^{1}$

At first, the minimum wage setting process was centralized and categorized into three zones by geographic region. From October 1981, the legislation stated that minimum wage setting should take factors of each region - such as inflation, living standard, competitiveness, and economic and labor market condition - into consideration. Although the national tripartite committee (comprising representatives from employers, employees and government) raised minimum wages around once a year (except for 1999 and 2000), the number of minimum wage zones was stable at around three-four zones during 19812001. After the enactment of the Labor Protection Act 1998, the minimum wage setting was decentralized from the national to regional tripartite sub-committee in each province or sub-region. Then the number of minimum wage zones started to increase dramatically from eight zones in 2002 to 28 zones in 2010. Yet differences among provinces broken away from the same zone are relatively small.

Figure 1 shows the real value of minimum wages in ten selected provinces including Bangkok and Phuket as well as the two provinces from the north, Phrae and Phayao, which are among the top two and bottom two of the minimum wage zones in 2010. Real minimum wages rose from the late 1980s until they reached their peak slightly before the 1997 Asian economic crisis. Then they dropped sharply and did not attain such levels again even in 2011.

Since its first implementation, violation of the law could result in being fined, imprisoned, or both. For example, the Labor Protection Act 1998 states that any employers paying wages lower than the legislative minimum are liable for a fine not exceeding 100,000 baht or up to six-month imprisonment or both. Based on minimum wages in 2001, the upper limit of this fine is worth more than 600 worker-days for every province, which is a sizable punishment for small and medium firms.

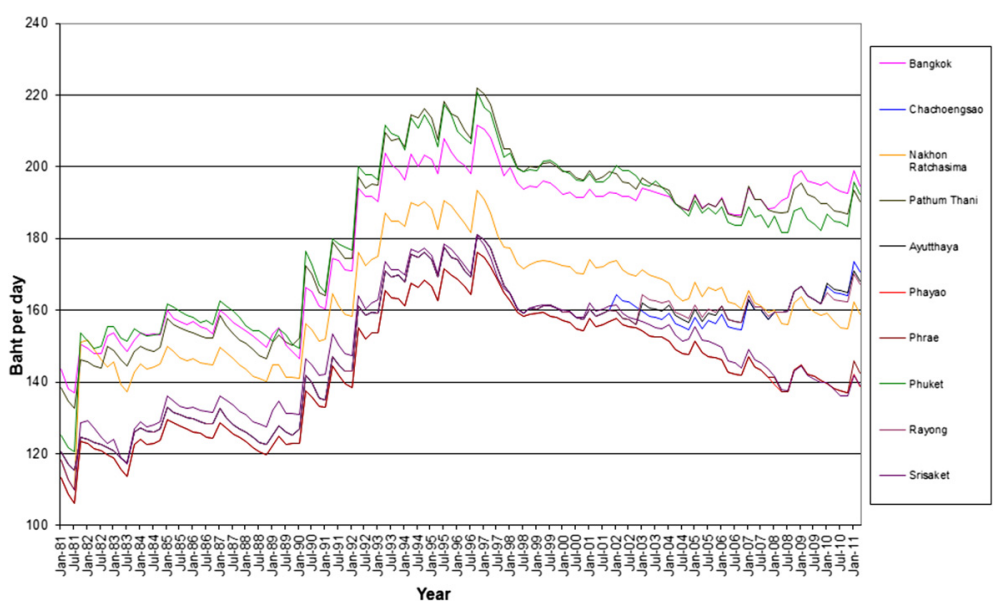

Fig. 1 The real minimum wages of selected provinces (Baht per day in 2007) 1981-2011. Note: To acquire the real value, nominal minimum wages in each province are adjusted by Consumer Price Index (CPI) at the regional level 
However, the effectiveness of the law enforcement is questionable. According to Table 1, although the labor inspection rate during $2006-2010$ was $12-13 \%$ of all establishments each year, more than $94 \%$ of firms violating any labor law received only a warning from the authority. Less than $0.3 \%$ of all wrong-doing establishments were fined or prosecuted. Although the non-compliance rate had been decreasing overtime from 4.7\% in 2006 (2,100 out of 44,658 establishments) to $1.26 \%$ in 2010 ( 625 out of 49,463 establishments), weak law enforcement in the earlier periods could contribute to either no effect on wage inequality or differential effects across different sectors. I will return to the consequences of weak law enforcement later.

\section{Data and descriptive analysis}

I employ the Labor Force Survey (LFS) conducted by the National Statistics Office of Thailand (NSO). NSO adopts a stratified two-stage sampling technique for the whole country (starting with blocks or villages and then private households) for these surveys. From 1984 to 1997 the surveys were conducted in three rounds in each year. The first round enumeration was held in February, coinciding with the nonagricultural season; the second round was normally held in May when the new labor force of graduated students had just finished their studies; and the third round was conducted in August, during the agricultural season. From 1998 to 2000, the fourth round of the survey was conducted in November (NSO 2003). Since 2001 the surveys have been conducted monthly, with three months combined for each round of surveys.

LFS provides data on individual characteristics for every member of the household including work status, occupation, industry and hours worked for all employed persons. Also, for all wage earners, the LFS records information on wage/salary, overtime payments, bonuses and some other fringe benefits in the first and third rounds. After 1999 this wage data also has been available for the second and fourth rounds. In order to ensure comparability across years, only the first and third rounds (dry and rainy seasons) of the LFS from 1985 to 2010 (with the exception of three rounds, which are $19861^{s t}, 19901^{\text {st }}$, and $20103^{\text {rd }}$ ) are utilized. Typically, the sample size of each survey is large and representative at regional level. Only after February 1994 did NSO expand the sample size to assure statistical representation at provincial level (NESDB and NSO 2004). ${ }^{2}$ Hence, due to the small sample size in these early surveys (especially for wage earners), this study will provide a robustness check where provinces and rounds with too few observations are dropped.

In this paper, the sample covers all wage earners in private, public and state enterprises who report their wages and the number of hours worked in the week preceding the survey. As the minimum wage law in Thailand primarily determines the basic wage for regular working hours - hourly wages excluding other compensation such as bonuses, over-time, clothes or any other benefits - these are used. Hourly wages are calculated from basic wage divided by total hours worked for principal occupation. In several cases, the total hours worked may contain hours of over time work. Since employers are required by law to pay over-time at a rate that is at least $50 \%$ higher than hourly wages during regular hours, I compare information on basic wage with over time payment adjusted by 1.5 in order to obtain the proportion of regular hours worked from the number of total hours worked. Although this procedure might overestimate the 
Table 1 Labor inspection in the whole country 2006-2010 (number of establishments)

\begin{tabular}{|c|c|c|c|c|c|c|c|c|c|c|}
\hline \multirow{3}{*}{ Year } & \multicolumn{2}{|c|}{ Establishments inspected } & \multicolumn{3}{|c|}{ Non-compliance with labor law } & \multicolumn{5}{|c|}{ Conduction of labor inspector } \\
\hline & \multirow{2}{*}{ Number } & \multirow{2}{*}{ Percentage } & \multirow{2}{*}{$\begin{array}{c}\text { All types of } \\
\text { illegal conduct }\end{array}$} & \multicolumn{2}{|c|}{ Minimum wage } & \multirow{2}{*}{$\begin{array}{l}\text { Warning } \\
\text { issued }\end{array}$} & \multirow{2}{*}{ Summon } & \multirow{2}{*}{$\begin{array}{c}\text { Order of } \\
\text { compliance }\end{array}$} & \multirow{2}{*}{ Fine } & \multirow{2}{*}{$\begin{array}{c}\text { Criminal action } \\
\text { submission }\end{array}$} \\
\hline & & & & Est. & Persons & & & & & \\
\hline 2006 & 44,658 & 11.89 & 7,982 & 2,100 & 7,730 & 7,570 & 251 & 145 & 6 & 10 \\
\hline 2007 & 50,993 & 13.37 & 7,725 & 2,005 & 6,752 & 7,300 & 329 & 76 & 11 & 9 \\
\hline 2008 & 47,940 & 12.54 & 5,667 & 1,287 & 4,018 & 5,509 & 118 & 38 & 2 & - \\
\hline 2009 & 50,669 & 12.99 & 5,150 & 880 & 4,137 & 4,946 & 119 & 76 & 2 & 7 \\
\hline 2010 & 49,463 & 12.49 & 2,447 & 625 & 4,033 & 2,366 & 50 & 26 & 1 & 4 \\
\hline
\end{tabular}

Source : Labor Standard Development Bureau, Department of Labor Protection and Welfare 
number of regular hours worked, it should provide a lower bound for the observed hourly wage.

According to the kernel density of log hourly wages in Fig. 2 where two vertical lines refer to minimum wages in each zone during July 2007 and 2008 respectively, male workers seem to earn slightly more than their female counterparts in all zones, as expected. Nevertheless, there is no distinct spike around the minimum wage in any zones. In Bangkok and the central region, peaks of female wage distributions are only slightly higher than the statutory minimum; on the contrary just around half of female workers in the north receive basic hourly wages that are higher than the minimum wages in their provinces. This result indicates a possibility of a severe non-compliance problem in many provinces, especially in the low minimum wage zones.

In Table 2, binding percentiles - fractions of employees in each province who receive wages less than the legislative minimum wage - of the minimum wage across provinces over the sample periods are presented. Though it does not show a clear upward trend in the rate of compliance with the minimum wage law, binding percentiles in provinces with the highest, middle, and lowest rates of non-compliance (referred in Table 2 as Max, Median, and Min pctile) decrease slightly over the period of study. Still, non-compliance rates in provinces in around half of the country were higher than $30 \%$ even in 2009 . Consequently, the wage compression effect from minimum wage laws might be partially effective. Various strategies to investigate this hypothesis will be discussed in the following section.

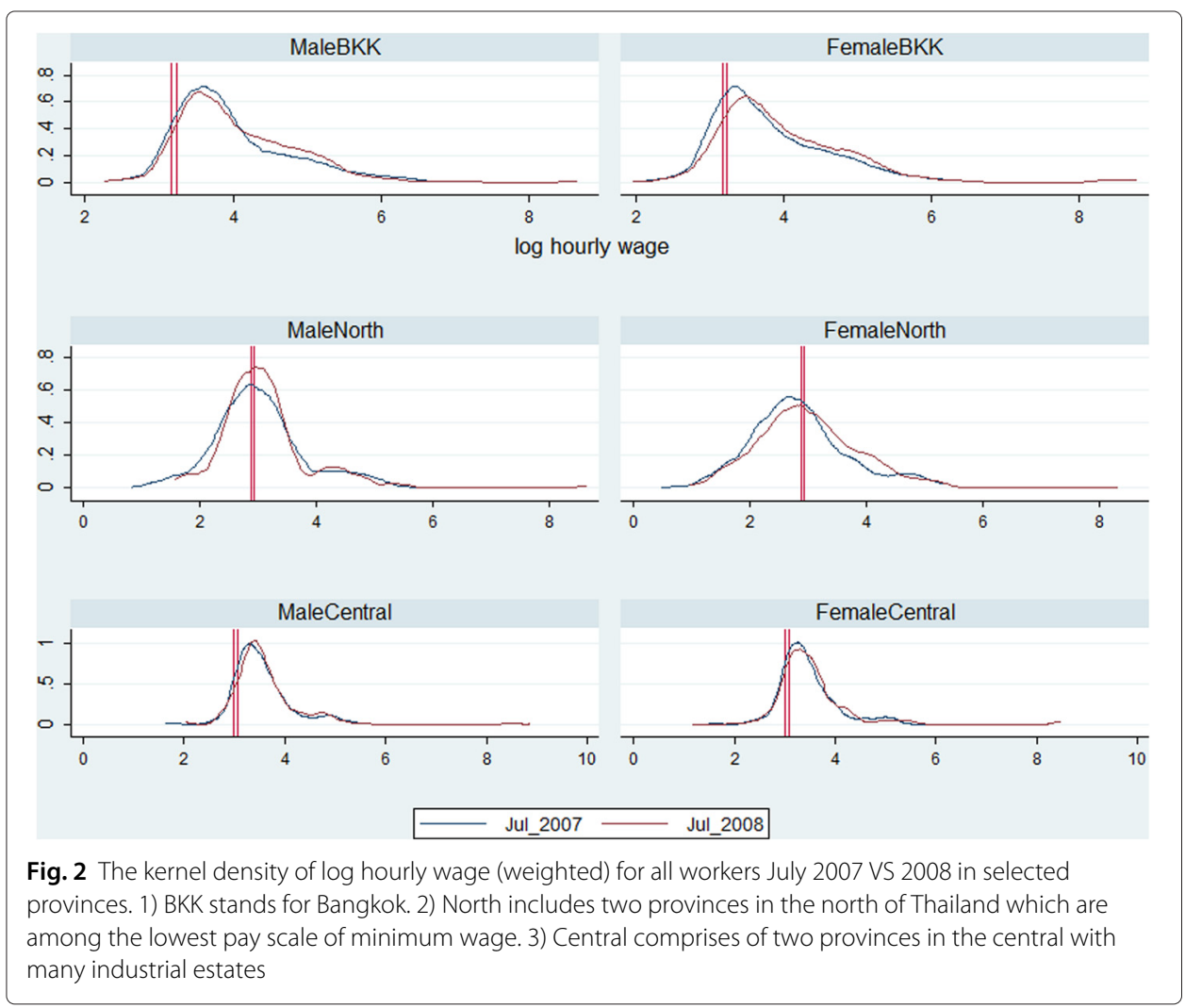


Table 2 Bindingness of the provincial minimum wages

\begin{tabular}{|c|c|c|c|c|c|c|c|c|c|}
\hline \multirow[b]{2}{*}{ Year(Q3) } & \multicolumn{3}{|c|}{ All } & \multicolumn{3}{|c|}{ Female } & \multicolumn{3}{|c|}{ Male } \\
\hline & $\begin{array}{l}\text { Max. } \\
\text { pctile }\end{array}$ & $\begin{array}{l}\text { Min. } \\
\text { pctile }\end{array}$ & $\begin{array}{l}\text { Median } \\
\text { pctile }\end{array}$ & $\begin{array}{l}\text { Max. } \\
\text { pctile }\end{array}$ & $\begin{array}{l}\text { Min. } \\
\text { pctile }\end{array}$ & $\begin{array}{l}\text { Median } \\
\text { pctile }\end{array}$ & $\begin{array}{l}\text { Max. } \\
\text { pctile }\end{array}$ & $\begin{array}{l}\text { Min. } \\
\text { pctile }\end{array}$ & $\begin{array}{l}\text { Median } \\
\text { pctile }\end{array}$ \\
\hline 1989 & 85.1 & 15.5 & 48.5 & 95.1 & 27.4 & 61.4 & 80.6 & 5.0 & 39.8 \\
\hline 1994 & 72.2 & 14.2 & 48.9 & 85.1 & 17.6 & 61.0 & 62.4 & 11.2 & 43.1 \\
\hline 1999 & 62.4 & 7.5 & 35.4 & 75.5 & 9.6 & 42.1 & 59.3 & 5.8 & 30.5 \\
\hline 2004 & 65.2 & 10.8 & 40.9 & 74.8 & 12.4 & 44.5 & 62.3 & 9.4 & 37.1 \\
\hline 2009 & 51.4 & 9.5 & 29.9 & 62.1 & 8.4 & 34.8 & 53.2 & 7.6 & 26.2 \\
\hline
\end{tabular}

The definition for Max. pctile, Min. pctile and Median pctile are as follows: All percentiles (pctile) display in this table are a proportion of workers who received basic wage less than their provincial minimum wage. For Max. pctile, it is such percentile in a province with the highest level of non-compliance to the law in each year. Meanwhile, Min. pctile is a percentile in a province with the highest compliance to the law whereas Median pctile is the percentile in a province with non-compliance rates at the middle of all provinces in that year

\section{Methodology}

This paper follows the empirical strategy used in the US literature by Lee (1999) as well as modifications suggested by Autor et al. (2010) to assess the effect of changes in the minimum wage on wage inequality in Thailand. Lee (1999) assumes that the level of wage inequality in state $\mathrm{n}$ (province $\mathrm{n}$ in this paper) at time $\mathrm{t}$ depends on the level of latent wage inequality (the one that would prevail if there was no minimum wage law) and the minimum wage. Therefore, the position of the minimum wage on the overall distribution of wages in that region (or its binding percentile) will determine the effect of the minimum wage on wage inequality. However, since the latent wage inequality is unobservable, the true bindingness (the position of the minimum wage on the wage distribution which is unaffected by the minimum wage) is also unmeasurable. So Lee (1999) proposes using the difference between the log median wage and the log of the statutory minimum wage in that region as a proxy for the bindingness; he then calls this difference the effective minimum.

If the key identifying assumption in Lee (1999) - that the cross-regional variation in latent wage inequality is uncorrelated with the median - holds, the coefficient of the effective minimum can be estimated consistently after controlling for time dummies. However, Autor et al. (2010) shows that in the US data, the levels of latent wage inequality are positively correlated with states' median wages. Therefore, to address omitted variables resulting from this correlation, state fixed effects should be included. In addition, recent studies such as Allegretto et al. (2010) provide evidence that state and time dummies cannot fully account for heterogeneity in underlying employment patterns in low-wage jobs. Hence, the regression model should also control for state-specific linear trends.

By including both provincial fixed effects and provincial linear trends like in Autor et al. (2010), this paper allows for the correlation between provincial latent wage inequality and its median as well as the possibility that changes in minimum wages could correlate with shocks to the wage distribution in each province. Thus, the main ordinary least squares (OLS) specification is:

$$
w_{n t}^{P}-w_{n t}^{M}=d_{t P}+d_{n P}+d_{n P} \times T+\beta_{1}^{P}\left(M W_{n t}-w_{n t}^{M}\right)+\beta_{2}^{P}\left(M W_{n t}-w_{n t}^{M}\right)^{2}+\epsilon_{n t}^{P}
$$

where $w_{n t}^{P}$ is the $P^{\text {th }}$ percentile of the observed log wage (per hour), $w_{n t}^{M}$ is the Median (this paper uses the 6th decile) of the observed log wage; $d_{t P}$ is the year dummy; $d_{n P}$ is the provincial dummy; $T$ is the time trend; $M W_{n t}$ is the statutory minimum wage; and $\epsilon_{n t}^{P}$ is an error term in province $\mathrm{n}$ at time $\mathrm{t}$ for the $P^{\text {th }}$ percentile. Also, all regressions are weighted by multiplication of sampling weight and number of total hours worked. 
Moreover, to tackle division bias, ${ }^{3}$ I follow a two-stage least squares (2SLS) strategy as in Card et al. (1993) and Autor et al. (2010) by using the effective minimum with statutory minimum wage in each province and year as an instrument. This instrument should be correlated to the provincial effective minimum but uncorrelated to any measurement errors in the sampling median. Thus, it relies on a key assumption that legislated changes in minimum wage are not correlated with changes in latent province wage inequality, conditional on year and province dummies and provincial trends. Therefore, the second stage is the same as in Eq. 4.1 while the first stage for the effective minimum is specified as:

$$
\left(M W_{n t}-w_{n t}^{M}\right)=d_{t P}+d_{n P}+d_{n P} \times T+\delta^{P} M W_{n t}+v_{n t}^{P}
$$

Likewise, an instrument for the square of the effective minimum is computed from the predicted value from regression 4.2 squared. Yet this instrument might suffer from limited variation because there were few minimum wage zones before 2002 . To bypass this problem and provide robustness checks for the 2SLS models, I adopt a reduced form approach from Autor et al. (2010) and use predicted instead of observed provincial median wage in Eq. 4.1. The predicted median can be estimated as follows:

$$
w_{n t}^{M}=d_{t}+d_{n}+d_{n} \times T+u_{n t}
$$

which specifies the provincial median wage, $\widehat{w_{n t}^{M}}$, as a function of year dummies, province dummies and provincial trends. Then I define the reduced form effective minimum $\widetilde{m w}_{n t}$ as $\left(M W_{n t}-\widehat{w_{n t}^{M}}\right)$. Equation 4.1 can be rewritten as:

$$
w_{n t}^{P}-w_{n t-1}^{P}=d_{t P}+d_{n P}+d_{n P} \times T+\tilde{\beta}_{1}^{P} \widetilde{m w}_{n t}+\tilde{\beta}_{2}^{P} \widetilde{m w}_{n t}^{2}+\tilde{\epsilon}_{n t}^{P}
$$

Further, the other identification strategy proposed in the literature called "fraction affected" (Card and Krueger 1995) is adopted so as to circumvent the potential weak instruments problem as well as a decline of the real minimum wage. The primary OLS model is specified as:

$$
w_{n t}^{P}-w_{n t-1}^{P}=c^{P}+\theta^{P}\left(F A_{n t}\right)+\eta_{n t}^{P}
$$

where $w_{n t}^{P}-w_{n t-1}^{P}$ is the change in log hourly wage at the $P^{t h}$ percentile from year t-1 to $\mathrm{t}$ in province $\mathrm{n} ; F A_{n t}$ is the fraction affected in province $\mathrm{n}$ in year $\mathrm{t}$, defined as the fraction of workers in year $\mathrm{t}-1$ who earn wages between the old and new minimum wages, i.e. between year t- 1 and $\mathrm{t} ; c^{P}$ is a constant; and $\eta_{n t}^{P}$ is an error term. In order to control for different labor market conditions across provinces, regressions which include average provincial wages in year $\mathrm{t}-1$ as a control are also presented.

Nevertheless, this technique relies on an assumption that workers directly affected by the increase in the minimum wage are those receiving wages either exactly at the former minimum wage or between the former and new minimum wages. Therefore, provinces with a higher fraction affected should show a larger effect on the lower part of wage distribution. I will present results only from selected years with a substantial increase in statutory minimum wages which in turn leads to potentially more variation in the fraction affected.

\section{Results}

To investigate the effect of minimum wages on wage inequality in developing countries, the compliance rate is one of the major concerns. Although employers in formal sectors 
are expected to comply with the minimum wage law, the LFS does not provide any information on the social security contribution of each worker which is widely used in the literature as an indication of being a formal worker. Instead, based on characteristics of workers and firms, this paper computes the non-compliance rate of each sub-group in the sample implicitly from the percentage of workers paid below the minimum wage.

Therefore, the results demonstrated in this section are classified into three groups according to coverage of the law and the compliance rate. Aiming to estimate the effect of the minimum wage on the overall wage distribution, the first group uses all employees in the sample regardless of their age, gender, or industry. The second group, however, focuses on male employees in private firms outside the agricultural sector. And thirdly, to capture the effectiveness of the minimum wage policy on wage inequality in the formal sector of the Thai labor market (as classified by firm size), the sample is further restricted to male employees in large private firms. ${ }^{4}$

Models 4.1 and 4.4 are employed to estimate the regression results in Tables 3, 4 and 5 for all three classifications of the sample respectively. The OLS regressions of all workers both with and without provincial trends yield positive and significant coefficients in all percentiles. These results coincide with the criticism about the division bias highlighted in Autor et al. (2010). ${ }^{5}$ The next two columns show the results after instrumenting the effective minimum and its squared term with the legislative minimum wage and the square of the predicted value from Eq. 4.2. The marginal effects of the 2SLS regressions without

Table 3 Effect of the minimum wage on log wage gap $\left(\log \left(\mathrm{p}^{\text {th }}\right)-\log (\mathrm{p} 60)\right)$ of selected percentiles, all workers (1985-2010)

\begin{tabular}{|c|c|c|c|c|c|c|}
\hline \multirow{2}{*}{ Percentile } & \multicolumn{2}{|c|}{ OLS } & \multicolumn{2}{|c|}{$2 S L S$} & \multicolumn{2}{|c|}{ Predicted median } \\
\hline & (1) & (2) & (1) & (2) & (1) & (2) \\
\hline \multirow[t]{2}{*}{5} & $0.72^{* * *}$ & $0.585^{* * *}$ & $3.973^{* * *}$ & -0.815 & $1.256^{* * *}$ & -1.041 \\
\hline & $(0.082)$ & $(0.042)$ & (1.003) & $(0.622)$ & $(0.401)$ & $(0.669)$ \\
\hline \multirow[t]{2}{*}{10} & $0.654^{* * *}$ & $0.578^{* * *}$ & $2.669^{* * *}$ & -0.308 & $0.956^{* * *}$ & -0.395 \\
\hline & $(0.059)$ & $(0.035)$ & $(0.67)$ & $(0.404)$ & $(0.255)$ & $(0.483)$ \\
\hline \multirow[t]{2}{*}{20} & $0.537^{* * *}$ & $0.55^{* * *}$ & $0.622^{* * *}$ & -0.304 & $0.462^{* * *}$ & -0.389 \\
\hline & $(0.031)$ & $(0.031)$ & $(0.214)$ & $(0.387)$ & $(0.08)$ & $(0.442)$ \\
\hline \multirow[t]{2}{*}{25} & $0.489^{* * *}$ & $0.524^{* * *}$ & 0.154 & -0.093 & $0.334^{* * *}$ & -0.119 \\
\hline & $(0.029)$ & $(0.026)$ & $(0.235)$ & $(0.322)$ & $(0.084)$ & $(0.404)$ \\
\hline \multirow[t]{2}{*}{30} & $0.433^{* * *}$ & $0.481^{* * *}$ & -0.128 & -0.031 & $0.225^{* * *}$ & -0.04 \\
\hline & $(0.03)$ & $(0.025)$ & $(0.224)$ & $(0.257)$ & $(0.082)$ & $(0.333)$ \\
\hline \multirow[t]{2}{*}{40} & $0.319^{* * *}$ & $0.367^{* * *}$ & -0.252 & 0.093 & $0.118^{*}$ & 0.119 \\
\hline & $(0.027)$ & $(0.022)$ & $(0.157)$ & $(0.153)$ & $(0.068)$ & $(0.217)$ \\
\hline \multirow[t]{2}{*}{75} & 0.008 & -0.015 & $0.502^{* *}$ & -0.08 & 0.113 & -0.102 \\
\hline & $(0.034)$ & $(0.028)$ & $(0.207)$ & $(0.198)$ & $(0.078)$ & $(0.264)$ \\
\hline \multirow[t]{2}{*}{90} & $0.293^{* * *}$ & $0.254^{* * *}$ & $0.915^{* *}$ & 0.152 & $0.471^{* * *}$ & 0.191 \\
\hline & $(0.058)$ & $(0.046)$ & $(0.407)$ & $(0.36)$ & $(0.171)$ & $(0.488)$ \\
\hline \multirow[t]{2}{*}{95} & $0.525^{* * *}$ & $0.495^{* * *}$ & 0.4 & 0.128 & $0.657^{* * *}$ & 0.162 \\
\hline & $(0.05)$ & $(0.041)$ & $(0.443)$ & $(0.382)$ & $(0.164)$ & $(0.518)$ \\
\hline F-test (weak IV) & & & 30.923 & 17.996 & & \\
\hline Year dummy & Yes & Yes & Yes & Yes & Yes & Yes \\
\hline Province dummy & Yes & Yes & Yes & Yes & Yes & Yes \\
\hline Provincial trend & No & Yes & No & Yes & No & Yes \\
\hline
\end{tabular}

Note: These coefficients are marginal effect calculated from linear and square terms of the effective minimum. Standard errors are clustered at provincial level and displayed in parentheses while ***,** and * indicate significant at $1 \%, 5 \%$ and $10 \%$ level respectively. Model (1) controls for time and province fixed effect while model (2) also controls for provincial trend 
Table 4 Effect of the minimum wage on log wage gap, sub-sample male private employees outside the agricultural sector (1985-2010)

\begin{tabular}{|c|c|c|c|c|c|c|c|c|}
\hline \multirow{3}{*}{ Percentile } & \multicolumn{4}{|c|}{ Adult workers } & \multicolumn{4}{|c|}{ Young workers } \\
\hline & \multicolumn{2}{|c|}{$2 S L S$} & \multicolumn{2}{|c|}{ Predicted median } & \multicolumn{2}{|c|}{$2 S L S$} & \multicolumn{2}{|c|}{ Predicted median } \\
\hline & (1) & (2) & (1) & (2) & (1) & (2) & (1) & (2) \\
\hline \multirow[t]{2}{*}{5} & 5.122 & -0.912 & -0.118 & $-1.178^{*}$ & $1.41^{* *}$ & $-1.204^{*}$ & $0.731^{* * *}$ & $-1.661^{* *}$ \\
\hline & $(3.556)$ & $(0.608)$ & $(0.198)$ & $(0.647)$ & $(0.601)$ & $(0.628)$ & $(0.264)$ & $(0.828)$ \\
\hline \multirow[t]{2}{*}{10} & 0.787 & -0.79 & -0.055 & $-1.02^{* *}$ & $1.011^{* * *}$ & -0.696 & $0.433^{* *}$ & -0.965 \\
\hline & $(1.234)$ & $(0.507)$ & $(0.141)$ & $(0.493)$ & $(0.361)$ & $(0.477)$ & $(0.186)$ & $(0.655)$ \\
\hline \multirow[t]{2}{*}{20} & -0.655 & -0.293 & 0.071 & -0.376 & 0.108 & -0.348 & $0.219^{*}$ & -0.487 \\
\hline & $(0.852)$ & $(0.301)$ & $(0.089)$ & $(0.34)$ & $(0.235)$ & $(0.401)$ & $(0.13)$ & $(0.534)$ \\
\hline \multirow[t]{2}{*}{25} & -0.902 & -0.227 & 0.066 & -0.291 & -0.005 & -0.325 & 0.172 & -0.456 \\
\hline & $(0.893)$ & $(0.264)$ & $(0.091)$ & $(0.308)$ & $(0.217)$ & $(0.318)$ & $(0.118)$ & $(0.41)$ \\
\hline \multirow[t]{2}{*}{30} & -1.454 & -0.209 & 0.092 & -0.269 & -0.035 & -0.197 & $0.203^{* *}$ & -0.276 \\
\hline & $(1.227)$ & $(0.269)$ & $(0.094)$ & $(0.322)$ & $(0.195)$ & $(0.267)$ & $(0.092)$ & $(0.356)$ \\
\hline \multirow[t]{2}{*}{40} & -1.111 & -0.058 & 0.111 & -0.073 & $-0.245^{*}$ & -0.041 & $0.144^{* *}$ & -0.05 \\
\hline & $(0.96)$ & $(0.211)$ & $(0.068)$ & $(0.27)$ & $(0.146)$ & $(0.191)$ & $(0.067)$ & $(0.267)$ \\
\hline \multirow[t]{2}{*}{75} & 1.944 & $-0.331^{* *}$ & -0.086 & $-0.425^{*}$ & -0.094 & $-0.334^{*}$ & -0.012 & $-0.467^{*}$ \\
\hline & $(1.521)$ & $(0.149)$ & $(0.094)$ & $(0.256)$ & $(0.102)$ & $(0.191)$ & $(0.066)$ & $(0.25)$ \\
\hline \multirow[t]{2}{*}{90} & 4.99 & -0.411 & -0.196 & -0.533 & 0.063 & -0.673 & 0.144 & -0.95 \\
\hline & $(3.832)$ & $(0.361)$ & $(0.243)$ & $(0.51)$ & $(0.234)$ & $(0.475)$ & $(0.14)$ & $(0.64)$ \\
\hline \multirow[t]{2}{*}{95} & 4.918 & -0.733 & -0.173 & $-0.942^{*}$ & 0.238 & $-1.173^{*}$ & 0.268 & $-1.606^{* *}$ \\
\hline & (3.743) & $(0.456)$ & $(0.306)$ & $(0.566)$ & $(0.332)$ & $(0.68)$ & $(0.221)$ & $(0.795)$ \\
\hline F-test (weak IV) & 2.565 & 18.458 & & & 21.023 & 9.807 & & \\
\hline Year dummy & Yes & Yes & Yes & Yes & Yes & Yes & Yes & Yes \\
\hline Province dummy & Yes & Yes & Yes & Yes & Yes & Yes & Yes & Yes \\
\hline Provincial trend & No & Yes & No & Yes & No & Yes & No & Yes \\
\hline
\end{tabular}

Note: Standard errors are in parentheses while ${ }^{* * *},{ }^{* *}$ and ${ }^{*}$ indicate significant at $1 \%, 5 \%$ and $10 \%$ level respectively

provincial trends (model (1)) - estimating from coefficients of the effective minimum and its squared term - are positive and significant in some percentiles. However, the results of 2SLS regressions with provincial trends are not significantly different from zero in any percentiles. Such a pattern indicates that the 2SLS estimations are not robust to the exclusion of provincial trends and hence, the regressions with provincial trends are preferable, owing to the potential correlation between changes in minimum wages and shocks to the wage distribution discussed earlier. Lastly, the regressions based on the predicted median with and without provincial trends as in Eq. 4.4 do confirm a pattern of results observed from the 2SLS. ${ }^{6}$ In particular, the minimum wage does not have any significant effects on wage inequality of all workers after taking provincial trends into account.

Table 4 presents the regression results of two different age groups from the sub-sample of male private employees outside agriculture. According to the legislation, the minimum wage applies to all workers, both part-time and full-time, in private companies outside the agricultural sector. However, the reason for choosing only the males instead of both genders is the higher prevalence of non-compliance among female laborers. So the results from this male sub-sample should provide an upper bound for the impact of the minimum wage policy in the so-called "covered sector". The 2SLS regressions of both adult and young workers do not show significant results in almost all percentiles. The only exception in the model with provincial trends are the $75^{\text {th }}$ percentile (for both age groups) and $95^{\text {th }}$ percentile (for the young) where minimum wage seems to compress workers' wage 
Table 5 Effect of the minimum wage on log wage gap, sub-sample private employees age 25-54 in large firms outside the agricultural sector (1987Q3 - 2010Q1) ${ }^{1}$

\begin{tabular}{|c|c|c|c|c|c|c|c|c|}
\hline \multirow{3}{*}{ Percentile } & \multicolumn{4}{|c|}{ All workers } & \multicolumn{4}{|c|}{ Only male workers } \\
\hline & \multicolumn{2}{|c|}{$2 S L S$} & \multicolumn{2}{|c|}{ Predicted median } & \multicolumn{2}{|c|}{$2 S L S$} & \multicolumn{2}{|c|}{ Predicted median } \\
\hline & (1) & (2) & (1) & (2) & (1) & (2) & (1) & (2) \\
\hline \multirow[t]{2}{*}{5} & -0.378 & $0.729^{*}$ & 0.083 & 1.337 & 0.551 & $0.519^{*}$ & 0.33 & 1.354 \\
\hline & $(1.013)$ & $(0.375)$ & $(0.262)$ & $(0.839)$ & $(0.694)$ & $(0.28)$ & $(0.215)$ & $(0.833)$ \\
\hline \multirow[t]{2}{*}{10} & -1.25 & $0.499^{*}$ & 0.239 & 0.927 & 0.174 & $0.543^{* *}$ & 0.281 & $1.418^{* *}$ \\
\hline & $(1.603)$ & $(0.283)$ & $(0.212)$ & $(0.676)$ & $(0.652)$ & $(0.22)$ & $(0.196)$ & $(0.603)$ \\
\hline \multirow[t]{2}{*}{20} & -0.688 & $0.63^{* *}$ & $0.404^{* * *}$ & $1.165^{* *}$ & 0.443 & $0.352^{* *}$ & 0.23 & $0.92^{*}$ \\
\hline & $(1.073)$ & $(0.247)$ & $(0.113)$ & $(0.59)$ & $(0.462)$ & $(0.149)$ & $(0.167)$ & $(0.513)$ \\
\hline \multirow[t]{2}{*}{25} & -0.478 & $0.649^{* * *}$ & $0.374^{* * *}$ & $1.192^{* *}$ & 0.516 & $0.415^{* * *}$ & $0.282^{* *}$ & $1.084^{* *}$ \\
\hline & $(0.913)$ & $(0.209)$ & $(0.094)$ & $(0.508)$ & $(0.377)$ & $(0.129)$ & $(0.118)$ & $(0.462)$ \\
\hline \multirow[t]{2}{*}{30} & -0.305 & $0.63^{* * *}$ & $0.363^{* * *}$ & $1.158^{* * *}$ & 0.489 & $0.412^{* * *}$ & $0.274^{* * *}$ & $1.074^{* *}$ \\
\hline & $(0.719)$ & $(0.192)$ & $(0.083)$ & $(0.403)$ & $(0.312)$ & $(0.124)$ & $(0.09)$ & $(0.432)$ \\
\hline \multirow[t]{2}{*}{40} & 0.214 & $0.478^{* * *}$ & $0.238^{* * *}$ & $0.879^{* * *}$ & 0.468 & $0.433^{* * *}$ & $0.157^{* *}$ & $1.128^{* * *}$ \\
\hline & $(0.354)$ & $(0.166)$ & $(0.058)$ & $(0.314)$ & $(0.333)$ & $(0.096)$ & $(0.07)$ & $(0.28)$ \\
\hline \multirow[t]{2}{*}{75} & 0.096 & -0.373 & -0.037 & $-0.671^{*}$ & 0.474 & 0.218 & 0.014 & 0.571 \\
\hline & $(0.353)$ & $(0.242)$ & $(0.071)$ & $(0.374)$ & $(0.394)$ & $(0.171)$ & $(0.068)$ & $(0.436)$ \\
\hline \multirow[t]{2}{*}{90} & 0.695 & -0.037 & $0.296^{* *}$ & -0.059 & 0.042 & 0.098 & 0.121 & 0.258 \\
\hline & $(0.877)$ & $(0.382)$ & $(0.146)$ & $(0.714)$ & $(0.528)$ & $(0.3)$ & $(0.155)$ & $(0.816)$ \\
\hline \multirow[t]{2}{*}{95} & -0.205 & 0.465 & $0.405^{* *}$ & 0.842 & -1.004 & -0.032 & 0.194 & -0.088 \\
\hline & $(0.909)$ & (0.519) & $(0.174)$ & $(1.01)$ & $(0.952)$ & $(0.562)$ & $(0.196)$ & $(1.535)$ \\
\hline F-test (weak IV) & 2.408 & 8.942 & & & 3.494 & 10.884 & & \\
\hline Year dummy & Yes & Yes & Yes & Yes & Yes & Yes & Yes & Yes \\
\hline Province dummy & Yes & Yes & Yes & Yes & Yes & Yes & Yes & Yes \\
\hline Provincial trend & No & Yes & No & Yes & No & Yes & No & Yes \\
\hline
\end{tabular}

Note: Standard errors are in parentheses while ${ }^{* * *},{ }^{* *}$ and ${ }^{*}$ indicate significant at $1 \%, 5 \%$ and $10 \%$ level respectively. ${ }^{1}$ This sample does not include both quarters of 2001 due to a change in definition of a variable "firm size" in that year

in these percentiles towards the median $\left(60^{\text {th }}\right.$ percentile). Moreover, the results from predicted median method with provincial trends show similar patterns of significance (at the $75^{\text {th }}$ and $95^{\text {th }}$ percentiles), with two additional negative coefficients at the bottom (the $5^{\text {th }}$ and $10^{\text {th }}$ percentiles for the adults and only the $5^{\text {th }}$ percentile for the young). It can be interpreted that the minimum wage might result in widening the wage gap between the median workers and the low-wage workers in this sub-sample, though the significance and direction of the results are not robust to an exclusion of provincial trends.

Lastly, we consider the sub-sample of adult workers in large private firms (with more than 100 workers) outside the agricultural sector. Since this group has the lowest percentage of sub-minimum wage workers among all three classifications, it is used to represent the "formal sector" of the Thai labor market. Table 5 illustrates that, after controlling for provincial trends, the minimum wage policy narrows the wage gap from the $20^{\text {th }}$ to $40^{\text {th }}$ percentiles and the median $\left(60^{\text {th }}\right.$ percentile) regardless of gender ${ }^{7}$ or model specifications $\left(2 \mathrm{SLS}^{8}\right.$ or predicted median). This result implies that female workers in large firms who normally receive lower wages than males also benefit from the policy. Further, the coefficients from regressions with provincial trends comply with the model's underlying assumption that the minimum wage should not affect the upper side of the wage distribution.

In sum, the minimum wage policy seems to have different impacts on wage inequality depending on segments of the labor market. Only low-paid workers in large private 
firms (which can be considered as the formal segment of labor market) benefit from such wage compression effect. However, workers in the lowest wage percentile $\left(5^{\text {th }}\right)$ in this subgroup still do not benefit from the policy (the marginal effects are significant at the $10 \%$ significance level only in the 2SLS model). Thus, non-compliance seems to be one of the important factors contributing to the failure to reduce wage inequality in both the formal and informal sectors through the minimum wage policy.

Yet the real minimum wage was eroded for more than a decade after the Asian financial crisis in 1997. This could be another factor contributing to such widened wage gaps. Using the LFS data in the third quarter of 1994/95 and 1996/97, this paper adopts an empirical strategy based on the fraction of workers affected by the minimum wage (Card and Krueger 1995) in order to assess the importance of this concern. These periods are chosen because they are the last two periods of sizable increase in minimum wages before the Asian financial crisis (around 8.6-9.8\% rise for every province in July 1995 and 8.2-8.7\% in October 1996 relative to July 1994 and 1996 respectively). Furthermore, descriptive statistics in Tables 6 and 7 show that the characteristics of every sub-group of workers (which are sub-minimum wage workers, directly affected workers and other workers with higher wages) in 1994-such as gender, age, average years of education and firm size-are roughly similar to those in 1996.

Tables 8 and 9 classify workers into three sub-groups as discussed earlier. To get comparable results between these sub-groups, I employ the data only in 32 provinces with sizable samples during these periods. Overall, there are very few percentiles with significant results at the 5\% level. While the minimum wage increase in July 1995 results in negative and significant effects on changes in wages of the $25^{\text {th }}$ and $30^{\text {th }}$ percentiles of sub-sample male private employees and large firm employees respectively, ${ }^{9}$ these results are not significant in the regressions without the average provincial wage as a control variable. Conversely, the minimum wage rise in October 1996 has a positive and significant effect on wage changes between 1997 and 1996 in the $30^{\text {th }}$ percentile of the

Table 6 Descriptive statistics of all employees in the LFS 1994 sample

\begin{tabular}{lllll}
\hline LFS 1994 & $\begin{array}{l}\text { Below Min } \\
\text { Wage 93 }\end{array}$ & $\begin{array}{l}\text { Between Min } \\
\text { Wage 94/93 }\end{array}$ & $\begin{array}{l}\text { Between Min } \\
\text { Wage 95/94 }\end{array}$ & $\begin{array}{l}\text { Above Min } \\
\text { Wage 95 }\end{array}$ \\
\hline \multirow{2}{*}{ Female } & 0.516 & 0.356 & 0.462 & 0.338 \\
& $(0.4998)$ & $(0.479)$ & $(0.4987)$ & $(0.4732)$ \\
Age & 30.443 & 29.370 & 27.755 & 34.102 \\
& $(12.0203)$ & $(10.1998)$ & $(8.8799)$ & $(9.9641)$ \\
Urban & 0.322 & 0.384 & 0.440 & 0.592 \\
Year of education & $(0.4673)$ & $(0.4867)$ & $(0.4965)$ & $(0.4915)$ \\
& 5.205 & 6.237 & 6.783 & 10.091 \\
Log hourly wage & $(2.4708)$ & $(2.8967)$ & $(2.9868)$ & $(4.821)$ \\
& 2.172 & 2.668 & 2.765 & 3.512 \\
Working hours per week & $(0.4041)$ & $(0.128)$ & $(0.139)$ & $(0.6039)$ \\
Firm size fewer than 10 ppl & 54.635 & 52.447 & 49.799 & 44.288 \\
& $(12.4123)$ & $(10.8359)$ & $(7.907)$ & $(9.6329)$ \\
Firm size more than 100 ppl & 0.577 & 0.388 & 0.186 & 0.192 \\
Obs (weighted) & $(0.494)$ & $(0.4875)$ & $(0.3893)$ & $(0.3939)$ \\
\hline
\end{tabular}


Table 7 Descriptive statistics of all employees in the LFS 1996 sample

\begin{tabular}{lllll}
\hline LFS 1996 & $\begin{array}{l}\text { Below Min } \\
\text { Wage } 94\end{array}$ & $\begin{array}{l}\text { Between Min } \\
\text { Wage 96/94 }\end{array}$ & $\begin{array}{l}\text { Between Min } \\
\text { Wage 97/96 }\end{array}$ & $\begin{array}{l}\text { Above Min } \\
\text { Wage } 97\end{array}$ \\
\hline \multirow{2}{*}{ Female } & 0.520 & 0.468 & 0.477 & 0.331 \\
& $(0.4996)$ & $(0.4991)$ & $(0.4995)$ & $(0.4707)$ \\
Age & 31.889 & 30.720 & 29.148 & 34.020 \\
& $(12.9363)$ & $(10.8289)$ & $(10.2624)$ & $(10.2763)$ \\
Urban & 0.313 & 0.379 & 0.418 & 0.546 \\
Year of education & $(0.4638)$ & $(0.4852)$ & $(0.4933)$ & $(0.4979)$ \\
& 5.080 & 5.817 & 6.081 & 9.454 \\
Log hourly wage & $(2.5717)$ & $(2.7148)$ & $(2.6229)$ & $(4.7432)$ \\
& 2.327 & 2.720 & 2.828 & 3.559 \\
Working hours per week & $(0.3617)$ & $(0.1107)$ & $(0.1359)$ & $(0.6093)$ \\
& 55.846 & 53.451 & 50.351 & 45.785 \\
Firm size less than $10 \mathrm{ppl}$ & $(12.8271)$ & $(12.0062)$ & $(8.0229)$ & $(9.7505)$ \\
& 0.596 & 0.385 & 0.251 & 0.223 \\
Firm size more than 100 ppl & $(0.4908)$ & $(0.4868)$ & $(0.4335)$ & $(0.4164)$ \\
Obs (weighted) & 0.098 & 0.159 & 0.422 & 0.208 \\
\hline
\end{tabular}

sub-sample of private employees outside the agricultural sector regardless of firm size. This result is still robust after controlling for the average provincial wage in the third quarter of 1996. Interestingly, with negative and significant coefficients in the $5^{\text {th }}$ and $10^{\text {th }}$ percentiles of all workers, the minimum wage hike in 1996 might have adversely affected the low-wage workers in the economy-wide wage distribution.

Table 8 Effect of the minimum wage on changes in log wages of different sub-samples from $3^{\text {rd }}$ quarter 1994 to 1995

\begin{tabular}{|c|c|c|c|c|c|c|}
\hline \multirow{2}{*}{ Percentile } & \multicolumn{2}{|c|}{ All workers } & \multicolumn{2}{|c|}{ Male private employees } & \multicolumn{2}{|c|}{ Large firms employees } \\
\hline & (1) & (2) & (1) & (2) & (1) & (2) \\
\hline \multirow[t]{2}{*}{5} & -0.375 & -0.389 & 0.880 & -0.711 & -0.320 & -0.692 \\
\hline & $(0.644)$ & $(0.514)$ & $(1.076)$ & $(0.664)$ & $(0.456)$ & $(0.486)$ \\
\hline \multirow[t]{2}{*}{10} & 0.111 & 0.102 & -0.00874 & -0.499 & 0.295 & -0.434 \\
\hline & $(0.463)$ & $(0.371)$ & (0.399) & $(0.318)$ & $(0.465)$ & $(0.413)$ \\
\hline \multirow[t]{2}{*}{20} & -0.386 & -0.394 & -0.0143 & -0.524 & 0.609 & -0.178 \\
\hline & $(0.357)$ & $(0.301)$ & $(0.468)$ & $(0.390)$ & $(0.419)$ & $(0.344)$ \\
\hline \multirow[t]{2}{*}{25} & -0.409 & $-0.416^{*}$ & -0.192 & $-0.544^{* *}$ & $0.791^{* *}$ & -0.0609 \\
\hline & $(0.274)$ & $(0.219)$ & $(0.243)$ & $(0.258)$ & $(0.386)$ & $(0.240)$ \\
\hline \multirow[t]{2}{*}{30} & -0.378 & -0.389 & 0.109 & -0.259 & 0.457 & $-0.312^{* *}$ \\
\hline & $(0.417)$ & $(0.276)$ & $(0.287)$ & $(0.224)$ & $(0.296)$ & $(0.145)$ \\
\hline \multirow[t]{2}{*}{40} & -0.217 & -0.228 & 0.0411 & -0.335 & 0.442 & -0.207 \\
\hline & $(0.389)$ & $(0.258)$ & $(0.304)$ & $(0.265)$ & $(0.372)$ & $(0.188)$ \\
\hline \multirow[t]{2}{*}{50} & 0.187 & 0.174 & 0.607 & 0.0254 & 0.232 & -0.203 \\
\hline & $(0.366)$ & $(0.233)$ & $(0.409)$ & $(0.211)$ & $(0.258)$ & $(0.186)$ \\
\hline \multirow[t]{2}{*}{75} & 0.0638 & 0.0580 & $-0.413^{* *}$ & $-0.530^{* * *}$ & 0.121 & -0.394 \\
\hline & $(0.529)$ & $(0.549)$ & $(0.184)$ & $(0.180)$ & $(0.369)$ & $(0.323)$ \\
\hline \multirow[t]{2}{*}{90} & 0.438 & 0.433 & 0.724 & 0.109 & 0.258 & -0.462 \\
\hline & $(0.704)$ & $(0.729)$ & $(0.496)$ & $(0.472)$ & $(0.381)$ & $(0.392)$ \\
\hline \multirow[t]{2}{*}{95} & -0.0351 & -0.0402 & -0.268 & -0.831 & 0.575 & -0.105 \\
\hline & $(0.512)$ & $(0.532)$ & $(0.822)$ & $(0.882)$ & $(0.573)$ & (0.628) \\
\hline Average wage & No & Yes & No & Yes & No & Yes \\
\hline
\end{tabular}

Note: Standard errors are in parentheses while ${ }^{* * *},{ }^{* *}$ and ${ }^{*}$ indicate significant at $1 \%, 5 \%$ and $10 \%$ level respectively 
Table 9 Effect of the minimum wage on changes in log wages of different sub-samples from $3^{\text {rd }}$ quarter 1996 to 1997

\begin{tabular}{|c|c|c|c|c|c|c|}
\hline \multirow{2}{*}{ Percentile } & \multicolumn{2}{|c|}{ All workers } & \multicolumn{2}{|c|}{ Male private employees } & \multicolumn{2}{|c|}{ Large firms employees } \\
\hline & (1) & (2) & (1) & (2) & (1) & (2) \\
\hline \multirow[t]{2}{*}{5} & $-0.833^{* *}$ & $-0.829^{* *}$ & -0.790 & $-1.120^{*}$ & -0.575 & -0.267 \\
\hline & $(0.307)$ & $(0.308)$ & $(0.477)$ & $(0.636)$ & $(0.578)$ & $(0.603)$ \\
\hline \multirow[t]{2}{*}{10} & $-0.732^{* *}$ & $-0.754^{* *}$ & 0.0343 & -0.170 & $-0.914^{*}$ & -0.763 \\
\hline & $(0.304)$ & $(0.324)$ & $(0.240)$ & $(0.309)$ & $(0.493)$ & $(0.548)$ \\
\hline \multirow[t]{2}{*}{20} & -0.163 & -0.151 & $0.856^{* *}$ & $0.749^{*}$ & 0.289 & 0.247 \\
\hline & $(0.341)$ & $(0.322)$ & $(0.324)$ & $(0.376)$ & $(0.189)$ & $(0.214)$ \\
\hline \multirow[t]{2}{*}{25} & -0.0793 & -0.0671 & $0.621^{* *}$ & 0.455 & 0.231 & 0.342 \\
\hline & $(0.372)$ & $(0.354)$ & $(0.270)$ & $(0.272)$ & $(0.209)$ & $(0.206)$ \\
\hline \multirow[t]{2}{*}{30} & -0.274 & -0.280 & $0.610^{* * *}$ & $0.489^{* *}$ & $0.395^{* *}$ & $0.591^{* * *}$ \\
\hline & $(0.297)$ & $(0.305)$ & $(0.205)$ & $(0.200)$ & $(0.170)$ & $(0.172)$ \\
\hline \multirow[t]{2}{*}{40} & -0.384 & -0.386 & -0.637 & -0.235 & 0.0170 & $0.440^{*}$ \\
\hline & $(0.266)$ & $(0.279)$ & $(0.705)$ & $(0.459)$ & $(0.290)$ & $(0.240)$ \\
\hline \multirow[t]{2}{*}{50} & -0.413 & -0.484 & -0.820 & -0.515 & -0.399 & 0.0953 \\
\hline & (0.395) & $(0.374)$ & $(0.599)$ & $(0.449)$ & $(0.457)$ & $(0.364)$ \\
\hline \multirow[t]{2}{*}{75} & -0.274 & -0.435 & -1.314 & -0.891 & -0.445 & -0.451 \\
\hline & $(0.515)$ & $(0.497)$ & $(0.966)$ & $(0.630)$ & $(0.384)$ & $(0.448)$ \\
\hline \multirow[t]{2}{*}{90} & -0.490 & -0.642 & -2.154 & -1.733 & -0.597 & -0.959 \\
\hline & $(0.893)$ & $(0.865)$ & $(1.476)$ & $(1.023)$ & $(0.468)$ & $(0.583)$ \\
\hline \multirow[t]{2}{*}{95} & -1.340 & -1.432 & $-3.977^{*}$ & $-3.577^{*}$ & -0.853 & -1.307 \\
\hline & $(0.882)$ & $(0.861)$ & $(2.220)$ & $(1.783)$ & $(1.080)$ & (1.099) \\
\hline Average wage & No & Yes & No & Yes & No & Yes \\
\hline
\end{tabular}

Although these tables portray conflicting results, the timing of the increase in minimum wage could be an explanation for this discrepancy. In particular, the minimum wage hike on July $1^{s t}, 1995$ is right at the beginning of the third quarter in 1995, whereas the rise in October $1^{\text {st }}, 1996$ is nine months before the third quarter of 1997. So it seems that the wage compression effect of the minimum wage depends on not only the market segmentation but also a time lag so that 'law-abiding' employers can change their wage accordingly. Nevertheless, the result from 1996/97 supports the claim that only the workers around the second and third deciles (in private firms outside the agricultural sector) receive higher wages as a result of the minimum wage policy.

After considering results from both methods, it can be concluded that the minimum wage does have very limited effects on wage inequality. Only employees in large private companies outside agriculture benefit from the wage compression effect. Yet within such a sub-group, workers with the lowest wage per hour still do not gain from the minimum wage law. Moreover, the series of incremental increases in minimum wages, especially after the Asian financial crisis, do not seem to be an important factor underlying such results. Thus, the ineffectiveness of law enforcement seems to be the most plausible explanation. The discussion section will address this argument in detail.

\section{Robustness checks}

One of the major concerns of using LFS data to analyze the wage inequality at the provincial level is the sample size for wage earners in each province. Moreover, the classification of samples into smaller sub-groups threatens the validity of observed percentiles of wages due to the smaller sample available for percentile calculation. To address this concern, I 
restrict the sample to those 32 provinces (the same as in Tables 8 and 9) which consistently have more than ten respondents in all three categories for any survey waves from 1994Q1 to 2010Q1. With the same number of province-quarters in all sub-groups, models 4.1 and 4.4 are re-estimated.

Regressions based on this restricted sample provide supporting evidence for the results in previous section. After controlling for provincial trends, changes in minimum wages do not have any significant effects (at the 5\% level) on wage distribution of all wage earners or adult male private employees outside agriculture (for brevity, the regression results are not shown but are available upon request). Therefore, the ineffectiveness of minimum wage policy in reducing wage inequality for the whole labor market, or even among eligible workers, is robustly pronounced. Hence, an exclusion of provinces with too small sample in some periods does not seem to alter the main result.

Tables 10 and 11 illustrates the effects of the minimum wage on wage gaps among workers in the 'formal' segment (large firms) and the 'informal' segment (small and medium firms) of the labor market. There is virtually no effect on the low-paid workers in the informal sector whereas after controlling for provincial trends in both model specifications, all percentiles in the lower part of the wage distribution $\left(5^{\text {th }}-40^{\text {th }}\right)$ experience positive and significant wage compression pressures towards the median. This result leads to a slightly different conclusion that, instead of just the $20^{\text {th }}-40^{\text {th }}$ percentiles, the whole lower part of the wage distribution is pushed closer to the median wage due to the minimum wage policy. This minor discrepancy could originate from the inclusion of

Table 10 Effect of the minimum wage on log wage gap, sub-sample private employees age 25-54 in large firms outside the agricultural sector in 32 provinces (1994-2010) ${ }^{1}$

\begin{tabular}{|c|c|c|c|c|c|c|}
\hline \multirow{2}{*}{ Percentile } & \multicolumn{2}{|c|}{ OLS } & \multicolumn{2}{|c|}{$2 S L S$} & \multicolumn{2}{|c|}{ Predicted median } \\
\hline & (1) & (2) & (1) & (2) & (1) & (2) \\
\hline \multirow[t]{2}{*}{5} & $0.728^{* * *}$ & $0.776^{* * *}$ & -0.23 & $1.603^{* * *}$ & $0.458^{* *}$ & $1.881^{*}$ \\
\hline & $(0.063)$ & $(0.059)$ & $(0.672)$ & $(0.609)$ & $(0.222)$ & $(0.98)$ \\
\hline \multirow[t]{2}{*}{10} & $0.718^{* * *}$ & $0.745^{* * *}$ & -0.482 & $1.084^{* * *}$ & $0.558^{* * *}$ & $1.268^{* *}$ \\
\hline & $(0.04)$ & $(0.041)$ & $(0.826)$ & $(0.266)$ & $(0.127)$ & $(0.569)$ \\
\hline \multirow{2}{*}{20} & $0.653^{* * *}$ & $0.673^{* * *}$ & 0.339 & $0.919^{* * *}$ & $0.532^{* * *}$ & $1.072^{* *}$ \\
\hline & $(0.031)$ & $(0.037)$ & $(0.339)$ & $(0.316)$ & $(0.077)$ & $(0.475)$ \\
\hline \multirow[t]{2}{*}{25} & $0.592^{* * *}$ & $0.613^{* * *}$ & 0.459 & $1.072^{* * *}$ & $0.48^{* * *}$ & $1.257^{* * *}$ \\
\hline & $(0.032)$ & $(0.035)$ & $(0.285)$ & $(0.337)$ & $(0.08)$ & $(0.438)$ \\
\hline \multirow[t]{2}{*}{30} & $0.531^{* * *}$ & $0.551^{* * *}$ & $0.51^{* *}$ & $1.076^{* * *}$ & $0.425^{* * *}$ & $1.261^{* * *}$ \\
\hline & $(0.034)$ & $(0.037)$ & $(0.221)$ & $(0.395)$ & $(0.067)$ & $(0.36)$ \\
\hline \multirow[t]{2}{*}{40} & $0.413^{* * *}$ & $0.432^{* * *}$ & $0.553^{* *}$ & $0.915^{* *}$ & $0.308^{* * *}$ & $1.072^{* * *}$ \\
\hline & $(0.026)$ & $(0.029)$ & $(0.225)$ & $(0.358)$ & $(0.056)$ & $(0.325)$ \\
\hline \multirow[t]{2}{*}{75} & 0.03 & $0.043^{*}$ & -0.145 & -0.594 & -0.073 & -0.705 \\
\hline & $(0.019)$ & $(0.024)$ & $(0.209)$ & $(0.48)$ & $(0.103)$ & $(0.5)$ \\
\hline \multirow[t]{2}{*}{90} & $0.241^{* * *}$ & $0.237^{* * *}$ & 0.852 & 0.291 & 0.263 & 0.336 \\
\hline & $(0.055)$ & $(0.054)$ & $(0.731)$ & (0.649) & $(0.227)$ & $(0.868)$ \\
\hline \multirow[t]{2}{*}{95} & $0.288^{* * *}$ & $0.292^{* * *}$ & 0.429 & 1.422 & 0.307 & 1.675 \\
\hline & $(0.072)$ & $(0.067)$ & $(0.727)$ & $(1.33)$ & $(0.308)$ & $(1.594)$ \\
\hline F-test (weak IV) & & & 1.749 & 2.535 & & \\
\hline Year dummy & Yes & Yes & Yes & Yes & Yes & Yes \\
\hline Province dummy & Yes & Yes & Yes & Yes & Yes & Yes \\
\hline Provincial trend & No & Yes & No & Yes & No & Yes \\
\hline
\end{tabular}

Note: Standard errors are in parentheses while ${ }^{* * *},{ }^{* *}$ and ${ }^{*}$ indicate significant at $1 \%, 5 \%$ and $10 \%$ level respectively. ${ }^{1}$ This sample does not include both quarters of 2001 due to a change in definition of a variable "firm size" in that year 
Table 11 Effect of the minimum wage on log wage gap, sub-sample private employees age 25-54 in small and medium firms outside the agricultural sector in 32 provinces $(1994-2010)^{1}$

\begin{tabular}{|c|c|c|c|c|c|c|}
\hline \multirow{2}{*}{ Percentile } & \multicolumn{2}{|c|}{ OLS } & \multicolumn{2}{|c|}{$2 S L S$} & \multicolumn{2}{|c|}{ Predicted median } \\
\hline & (1) & (2) & (1) & (2) & (1) & (2) \\
\hline \multirow[t]{2}{*}{5} & $0.364^{* * *}$ & $0.426^{* * *}$ & 8.731 & -0.073 & -0.163 & -0.056 \\
\hline & $(0.108)$ & $(0.118)$ & (7.926) & $(1.707)$ & $(0.5)$ & (1.332) \\
\hline \multirow[t]{2}{*}{10} & $0.432^{* * *}$ & $0.496^{* * *}$ & 5.429 & -0.956 & -0.182 & -0.702 \\
\hline & $(0.102)$ & $(0.101)$ & $(5.202)$ & (1.576) & $(0.339)$ & $(1.067)$ \\
\hline \multirow{2}{*}{20} & $0.449^{* * *}$ & $0.5^{* * *}$ & 0.835 & -0.045 & 0 & -0.025 \\
\hline & $(0.064)$ & $(0.062)$ & $(1.657)$ & $(0.738)$ & $(0.201)$ & $(0.573)$ \\
\hline \multirow[t]{2}{*}{25} & $0.468^{* * *}$ & $0.523^{* * *}$ & -0.117 & -0.438 & -0.049 & -0.315 \\
\hline & $(0.054)$ & $(0.054)$ & $(1.251)$ & $(0.798)$ & $(0.182)$ & $(0.531)$ \\
\hline \multirow[t]{2}{*}{30} & $0.406^{* * *}$ & $0.454^{* * *}$ & -0.625 & -0.221 & -0.031 & -0.167 \\
\hline & $(0.044)$ & $(0.044)$ & $(1.008)$ & $(0.542)$ & $(0.151)$ & $(0.384)$ \\
\hline \multirow[t]{2}{*}{40} & $0.298^{* * *}$ & $0.328^{* * *}$ & -0.555 & -0.124 & 0.028 & -0.088 \\
\hline & $(0.035)$ & $(0.038)$ & $(0.667)$ & $(0.428)$ & $(0.105)$ & $(0.323)$ \\
\hline \multirow[t]{2}{*}{75} & $0.116^{* * *}$ & $0.115^{* *}$ & 0.058 & 0.848 & $0.171^{* *}$ & $0.627^{* *}$ \\
\hline & $(0.04)$ & $(0.046)$ & $(0.402)$ & $(0.585)$ & $(0.071)$ & $(0.308)$ \\
\hline \multirow[t]{2}{*}{90} & $0.176^{* *}$ & $0.172^{*}$ & 1.086 & 0.672 & 0.243 & 0.478 \\
\hline & $(0.089)$ & $(0.09)$ & $(1.412)$ & $(0.819)$ & $(0.221)$ & $(0.516)$ \\
\hline \multirow[t]{2}{*}{95} & 0.128 & 0.097 & 2.782 & 1.015 & 0.441 & 0.742 \\
\hline & $(0.108)$ & $(0.104)$ & $(2.716)$ & $(1.117)$ & $(0.298)$ & $(0.68)$ \\
\hline F-test (weak IV) & & & 0.828 & 2.362 & & \\
\hline Year dummy & Yes & Yes & Yes & Yes & Yes & Yes \\
\hline Province dummy & Yes & Yes & Yes & Yes & Yes & Yes \\
\hline Provincial trend & No & Yes & No & Yes & No & Yes \\
\hline
\end{tabular}

Note: Standard errors are in parentheses while ${ }^{* * *},{ }^{* *}$ and ${ }^{*}$ indicate significant at $1 \%, 5 \%$ and $10 \%$ level respectively. ${ }^{1}$ This sample does not include both quarters of 2001 due to a change in definition of a variable "firm size" in that year

the sample of provinces with too few respondents in some survey rounds. Hence, some outliers might influence those insignificant results among the $5^{\text {th }}$ and $10^{\text {th }}$ percentiles described in the previous section without affecting results of the more robust data from these 32 provinces. ${ }^{10}$ Thus, wage compression effects of the minimum wage law among these large firms could be stronger than what Table 5 suggests.

\section{Discussion}

The evidence for the impacts of minimum wages on wage inequality in Thailand suggests that the wage compression effect is confined to only low-paid workers in the formal sector of the labor market (as classified by firm size). Although increases in the minimum wage did not fully compensate for the rise in inflation after the Asian financial crisis, it is shown that this is unlikely to be the major force behind the result. Specifically, even in the years with a significant increase in real minimum wages, the impact of minimum wages is still determined by market segmentation. Therefore, imperfect compliance with the minimum wage law (not non-coverage ${ }^{11}$ ), especially in the informal sector, is the most plausible factor driving this pattern. There are two explanations for the observed high non-compliance rates. First, non-compliance could result from employers' expectation on the cost of paying sub-minimum wages. As discussed in Section 2, despite the relatively high upper limit of the fine and possible imprisonment for violating employers, the probability of being caught and severely punished is literally zero. Thus, this weak law enforcement is in line with the ineffective minimum wage policy observed. Moreover, 
Basu et al. (2007) show that such a weak enforcement of minimum wage policy can be an equilibrium phenomenon for a government with a credibility problem under a model with imperfect competition, imperfect enforcement and imperfect commitment.

On the other hand, the efficiency wage theory could explain higher compliance among larger firms. Rebitzer and Taylor (1995) set up a simple efficiency wage model where employers use dismissal as a disciplinary device to prevent shirking. Further, they assume that the supervisory resources of firms are fixed and the firms' capacity to closely supervise is decreasing with the number of employees. Acknowledging skepticism of monitoring difficulties as an explanation for employer size wage premia, Rebitzer and Taylor (1995) refer to both theoretical and empirical studies which suggest that the monitoring and incentive problem still persist in incentive schemes with minimal monitoring difficulties such as the piece rate. So an increase in minimum wages raises the cost of dismissal and induces workers in large firms to assert higher effort. Using the survey data from the UK residential care homes industry after the introduction of the National Minimum Wage in 1999, Georgiadis (2013) finds the evidence that supports this efficiency wage hypothesis.

Better compliance in large firms can be depicted from the data through kernel density and cumulative distribution plots of log hourly wages in Figs. 3 and 4. The peak of wage distribution in the formal sector (large firms) is around the highest provincial minimum

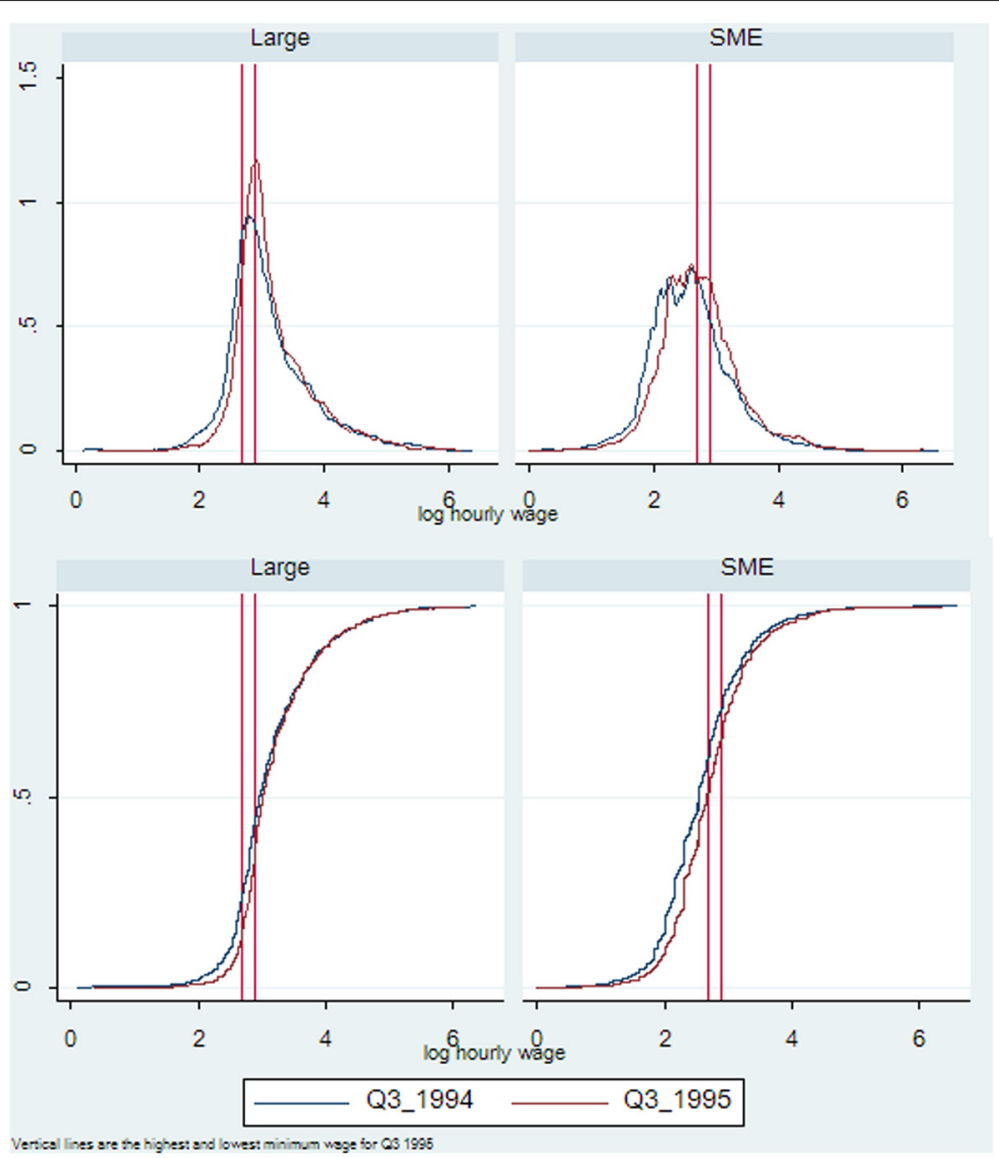

Fig. 3 The kernel density and cumulative distribution of log hourly wage (weighted) in Thailand for the formal (Large firms) and the informal (SME) workers $3^{\text {rd }}$ quarter 1994 VS 1995 


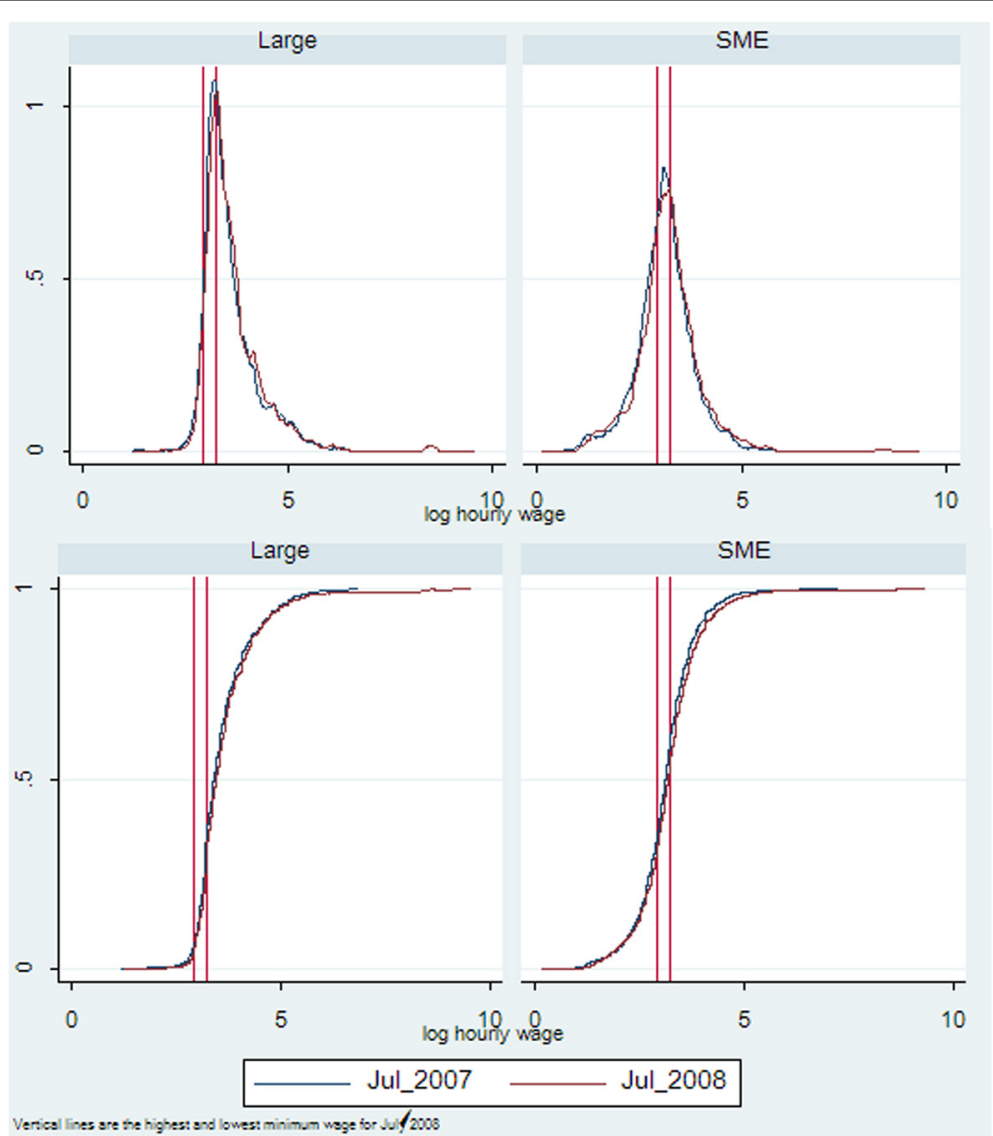

Fig. 4 The kernel density and cumulative distribution of log hourly wage (weighted) in Thailand for the formal (Large firms) and the informal (SME) workers July 2007 VS 2008

wage in both 1995 and 2008, whereas the peak prevails among informal workers (employees in small and medium firms) after a strong surge in compliance rates of both sectors in the 2000s.

It is worth noting that our discussion of the compliance problem and ineffectiveness of minimum wage policy is consistent with the segmented labor market (or two-sector) models such as Lewis (1954); Harris and Todaro (1970); Gramlich (1976); Mincer (1974) and Welch (1974) in many aspects. First, wage compression effects happen only in the formal sector with a single peak of the wage distribution around the legislative minimum wage. Second, those informal workers in the covered sector do not appear to experience any wage compression effects. Moreover, the legislative minimum wage does not generate any spikes in the informal wage distribution except for some recent periods of expansion in compliance. These observations are in accordance with the prediction of the WelchGramlich-Mincer two-sector model if the formal sector is treated as a covered sector while the informal one is treated as an uncovered sector. ${ }^{12}$ However, this conclusion is opposed to many analyses in Latin America (such as Lemos 2009; Maloney 1998; Pratap and Quintin 2006) which conclude that the two-sector model does not seem to correctly predict the wage and employment effects of the minimum wage law in spite of a sizable informal sector. Specifically, these papers find significant wage compression effects in both formal and informal sectors but no adverse effects on employment. 
Nonetheless, since the employment effect of minimum wage law is beyond the scope of this paper, it is not clear whether a significant fall in total employment as predicted by the Welch-Gramlich-Mincer model will be found in Thai data. In order to explore such topic, a more concrete definition of formal workers, which does not depend on being employed, has to be adopted. In particular, without good employment history or panel data, it is difficult or impossible to assign any unemployed workers to either large or small firms. Otherwise, other proxies for the formal sector such as social security entitlement must be used. The main challenge, however, is that the LFS data during these entire periods do not contain such information.

\section{Conclusion}

This paper examines the impact of the minimum wage policy on wage inequality in Thailand using the Labor Force Survey in the first and third quarters from 1985 to 2010. The evidence suggests that the minimum wage does not significantly affect overall wage distribution after allowing for different provincial trends. Despite restricting the sample to the covered sector, the minimum wage does not help compress the lower part of wage distribution towards the median. Conversely, it might widen wage gaps between the lowest decile and the median, though such a result is not robust. The wage compression effect is detected only after confining the sample to formal workers (classified by firm size) in the covered sector. These findings are robust to different empirical strategies and are not driven by small sample sizes in any provinces or periods. Hence, the difference in compliance rate between the formal and informal sectors (not between the covered and uncovered sectors) seems to be the prominent factor behind the fragmented effects of the minimum wage policy on wage inequality.

As for policy implication, the weak law enforcement seems to partly sustain subminimum pay among small firms in the covered sector. Without tackling the noncompliance issue, minimum wages will not be effective in creating a wage floor for low-paid workers in small firms (the informal sector), but might serve as another form of collective wage setting between formal workers and their employers through regional tripartite sub-committees. Yet better enforcement and higher compliance could potentially (but not always) lead to higher unemployment among low-paid workers.

In terms of theoretical models, the empirical results seem to coincide with the standard two-sector model's prediction. However, to draw any conclusion, sectoral employment effects need to be verified. This is beyond the scope of this paper and requires additional information to properly distinguish formal workers from their informal counterparts. In addition, one possible extension of the models is to incorporate the self-employed into the analysis. Although the self-employed are not covered by the minimum wage, comparing self-employed to uncovered workers as well as informal workers in the covered sector could provide interesting findings.

Lastly, it is worth noting that the Thai government just implemented the largest twostep minimum wage hikes in 2012 and 2013 which led to a single national minimum wage at 300 baht per day. ${ }^{13}$ This movement coincides with a two-step reduction in corporate income tax from $30 \%$ to $23 \%$ and from $23 \%$ to $20 \%$ on January 1,2012 and 2013 respectively (excluding some small enterprises subject to a lower tax rate and foreign businesses under the Board of Investment scheme). Although the government claims that the main objective of corporate tax reduction is to increase businesses' competitiveness 
in preparation for the beginning of the ASEAN Economic Community (AEC) in 2015, ${ }^{14}$ it is arguable that the tax reduction not only offers businesses (particularly in the formal sector) some compensation for the minimum wage hikes but also weakens any resistance of employers in the national tripartite committee. ${ }^{15}$ Such a parallel move could provide an opportunity to assess impacts of the minimum wage on employment and wage distribution among different segments of the Thai labor market, particularly any disparities between large and small firms in the covered sector.

\section{Endnotes}

${ }^{1}$ There is an exception for some hazardous jobs as defined by the Ministry of Labor (such as jobs related to work under water, inside tunnels, or involving hazardous chemicals or radioactive materials). Employees in these jobs are not allowed to work more than seven hours per regular working day. Yet this paper disregards such an exception and transforms the minimum wage per day into an hourly rate by dividing the statutory minimum wage per day by eight.

${ }^{2}$ The sample size of employees for the whole country in the third round ranges from 13,313 (out of a total of 78,214 persons) in 1985 to $37,828(177,821$ ) in 1994 and 53,342 $(219,538)$ in 2007.

${ }^{3}$ This bias results from a spurious correlation between the variables (Borjas 1980). In this case, the median of the observed log wage (potentially measured with errors) is used on both sides of the regression equation.

${ }^{4}$ Bindingness percentiles of provincial minimum wages of the second and third sub-samples are available upon request.

${ }^{5}$ The results from OLS regressions of the other two sub-samples also suffer from the division bias problem. Thus, they will not be shown.

${ }^{6}$ Weak instruments is one of the major concerns for 2SLS regression. The last row of Table 3 presents the Kleibergen-Paap rk Wald F-statistic for a weak identification test of the first-stage regression in each column. The F-statistics are the same for every percentile because the same set of endogenous regressors and instrumental variables is employed. These F-statistics in Tables 3 and 4 are significantly larger than the Stock-Yogo weak ID test critical value at 10\% (Stock and Yogo 2005). Hence, weak instruments is not an issue for the 2SLS estimations of all employees and the sub-sample of male private employees outside agriculture.

${ }^{7}$ At the $5 \%$ significance level, the wage compression effect also extends to the $10^{\text {th }}$ percentile of the males only.

${ }^{8}$ Although the F-statistic for first-stage regression of 2SLS without provincial trends is too low to reject the null hypothesis of weak identification, the first-stage regression of 2SLS with provincial trends does have a significantly high F-statistic.

${ }^{9}$ In addition, there is a robust negative and significant result (at the $5 \%$ level) for the $75^{\text {th }}$ percentile of sub-sample male private employees. It implies that the change in wages from 1994 to 1995 for this specific percentile is smaller in the province with a higher fraction of workers affected by the minimum wage. Unless there exist significant spillover effects or measurement errors in wages per hour (Autor et al. 2010), this interpretation is at odds with the fact that the binding of the minimum wage in any provinces does not exceed the $65^{\text {th }}$ percentile for this sub-sample in those periods. Hence, I decide not to discuss this counter-intuitive sign of coefficients in this paper.

${ }^{10}$ However, the insignificant Kleibergen-Paap rk Wald F-statistics for all 2SLS in Tables 10 and 11 raise a concern about weak identification of instrumental variables. This might be a result of restricting the sample to just 32 out of 76 provinces. All in all, the weak identification problem does not invalidate the whole results because models based on the predicted median still consistently provide supporting evidence for the same conclusion. 
${ }^{11}$ Unlike developed countries, where non-coverage can be one of the major concerns, developing countries seems to suffer more from non-compliance even in the covered sector (Strobl and Walsh 2003).

${ }^{12}$ Though median wages of the informal sector in the data are lower than in its formal counterpart, the Gramlich-Mincer version of the model does not unambiguously predict the direction of wage in the uncovered (or informal) sector after the minimum wage is imposed (Brown 1999).

${ }^{13}$ On April 1, 2012, in order to push the minimum wage in provinces with the highest band to 300 baht per day, minimum wages in every province were raised by approximately $40 \%$. Then on January 1,2013, minimum wages in the rest of the country were lifted to 300 baht per day. This resulted in almost doubling minimum wages among provinces in the lowest minimum wage band.

${ }^{14}$ Alexander, S., Salze-Lozac'h, V., \& Winijkulchai, A.: Thailand adopts nationwide minimum wage policy amid controversy, Asia Foundation, January 30, 2013.

${ }^{15}$ Parker, J.: Thailand introduces nationwide minimum wage, The Diplomat, January 11, 2013.

\section{Competing interests}

The IZA Journal of Labor \& Development is committed to the IZA Guiding Principles of Research Integrity. The author declares that he has observed these principles.

\section{Acknowledgments}

This paper is part of my doctoral thesis at London School of Economics and Political Science, under the supervision of Alan Manning and Steve Pischke, whom I would like to thank for their continual guidance and support. I also thank Guy Michaels, Barbara Petrongolo, Augustin de Coulon, Joanna Swaffield, David Waugh and Suporn Pongnumkul for their invaluable comments. The paper also benefited from comments of participants in the Thailand Development Research Institute (TDRI) seminar series and Oxford's Project Southeast Asia. I am grateful to the National Statistics Office, Kamphol Pantakua, and other colleagues at TDRI for the data and technical support. Comments by the editor and two anonymous referees greatly helped to improve an earlier version of this manuscript.

Responsible editors: Haroon Bhorat, Ravi Kanbur and Li Shi.

Received: 29 January 2015 Accepted: 28 September 2015

Published online: 10 December 2015

\section{References}

Allegretto S, Dube A, Reich M (2010) Do minimum wages really reduce teen employment? accounting for heterogeneity and selectivity in state panel data. Institute for Research on Labor and Employment, Working Paper Series qt7jq2q3j8. Institute of Industrial Relations, UC Berkeley

Autor DH, Manning A, Smith CL (2010) The contribution of the minimum wage to U.S. wage inequality over three decades: a Reassessment. Technical report, Centre for Economic Performance, LSE. CEP Discussion Papers

Basu AK, Chau N, Kanbur R (2007) Turning a blind eye: Costly enforcement, credible commitment and minimum wage laws. IZA Discussion Papers 2998. Institute for the Study of Labor (IZA)

Bird K, Manning C (2008) Minimum wages and poverty in a developing country: Simulations from Indonesia's household survey. World Dev 36(5):916-933

Boeri T, Garibaldi P, Ribeiro M (2010) Behind the lighthouse effect. IZA Discussion Papers 4890. Institute for the Study of Labor (IZA)

Borjas GJ (1980) The relationship between wages and weekly hours of work: the role of division bias. J Hum Res 15(3):409-423

Bosch M, Manacorda M (2010) Minimum wages and earnings inequality in urban Mexico. Am Econ J Appl Econ 2(4):128-49

Brown C (1999) Minimum wages, employment, and the distribution of income. Handbook of Labor Economics, Vol. 3. Elsevier, Cambridge, M.A. Chap. 32

Card D, Krueger A (1994) A living wage? The effects of the minimum wage on the distribution of wages, the distribution of family earnings, and poverty. Technical report, Princeton University, Department of Economics, Industrial Relations Section. Working Papers

Card D, Katz LF, Krueger AB (1993) An evaluation of recent evidence on the employment effects of minimum and subminimum wages. National Bureau of Economic Research, Inc

Card DE, Krueger AB (1995) Myth and Measurement: the New Economics of the Minimum Wage. Princeton University Press, Princeton, N.J.

Dickens R, Manning A (2004) Has the national minimum wage reduced UK wage inequality? J R Stat Soc Series A (Stat Soc) 167(4):613-626

DiNardo J, Fortin NM, Lemieux T (1996) Labor market institutions and the distribution of wages, 1973-1992: a semiparametric approach. Econometrica 64(5):1001-44

Fortin NM, Lemieux T (2000) 6. Income redistribution in Canada: minimum wages versus other policy instruments. In: Riddell WC, St-Hilaire F (eds). Adapting Public Policy to a Labour Market in Transition. Institute for Research on Public Policy (IRPP), Montreal. pp 211-247 
Freeman AC, Freeman RB (1992) When the minimum wage really bites: The effect of the U.S,-level minimum on Puerto Rico. In: Immigration and the Workforce: Economic Consequences for the United States and Source Areas. NBER Chapters. National Bureau of Economic Research, Inc, Chicago. pp 177-212

Georgiadis A (2013) Efficiency wages and the economic effects of the minimum wage: Evidence from a low-wage labour market. Oxf Bull Econ Stat 75(6):962-979

Gindling TH, Terrell K (2009) Minimum wages, wages and employment in various sectors in Honduras. Labour Econ 16(3):291-303

Gramlich EM (1976) Impact of minimum wages on other wages, employment, and family incomes. Brookings Papers Econ Act 7(2):409-462

Harris JR, Todaro MP (1970) Migration, unemployment \& development: A two-sector analysis. Am Econ Rev 60(1):126-42

Harrison AE, Leamer E (1997) Labor markets in developing countries: An agenda for research. J Labor Econ 15(3):1-19

Jomo KS (2006) Growth with equity in East Asia? Working papers, United Nations, Department of Economics and Social Affairs

Khamis M (2013) Does the minimum wage have a higher impact on the informal than on the formal labour market? evidence from quasi-experiments. Appl Econ 45(4):477-495

Lathapipat D (2008) The changing educational distribution and its impact on the evolution of wages in Thailand, 1987-2006. EABER Working Papers 21951. East Asian Bureau of Economic Research, (January 2008)

Lathapipat, D (2009) Changes in the Thai Wage Structure Before and after the 1997 Economic Crisis. Working Paper. http://dx.doi.org/10.2139/ssrn.1483584

Lee DS (1999) Wage inequality in the United States during the 1980s: Rising dispersion or falling minimum wage? Q J Econ 114(3):977-1023

Lemos S (2009) Minimum wage effects in a developing country. Labour Econ 16(2):224-237

Lewis WA (1954) Economic development with unlimited supplies of labour. Manch Sch 22(2):139-191

Machin S, Manning A (1994) The effects of minimum wages on wage dispersion and employment: Evidence from the U.K. wages councils. Ind Labor Relat Rev 47(2):319-329

Machin, S, Manning A (1997) Minimum wages and economic outcomes in Europe. Eur Econ Rev 41(3-5):733-742

Maloney WF (1998) Are labor markets in developing countries dualistic? Policy Research Working Paper Series 1941, The World Bank (June 1998)

Maloney WF, Mendez JN (2003) Measuring the impact of minimum wages: Evidence from Latin America. Technical report, National Bureau of Economic Research, Inc. NBER Working Papers

Maloney WF, Nunez J, Cunningham W, Fiess N, Montenegro C, Murrugarra E, Santamaria M, Sepulveda C (2001) Measuring the impact of minimum wages: Evidence from Latin America. Technical report, The World Bank. Policy Research Working Paper Series. http://elibrary.worldbank.org/doi/abs/10.1596/1813-9450-2597

Mincer J (1974) Unemployment effects of minimum wages. NBER Working Papers 39. Working Paper, National Bureau of Economic Research

NESDB, NSO (2004) The Measurement of the Non-Observed Economy in Thailand National Accounts. In: OECD/UNESCAP/ADB Workshop on Assessing and Improving Statistical Quality: Measuring the Non-Observed Economy, Bangkok, Thailand. National Economic and Social Development Board and National Statistical Office Neumark D, Wascher WL (2008) Minimum Wages. MIT Press, Cambridge, M.A.

NSO (2003) Report of the Labor Force Survey, whole Kingdom, Quarter 4 (October-December 2003). Technical report, National Statistical Office of Thailand. Bangkok

Pratap S, Quintin E (2006) The informal sector in developing countries: Output, assets and employment. UNU-WIDER Working Papers RP2006/130. World Institute for Development Economic Research. url=https://ideas.repec.org/p/ unu/wpaper/rp2006-130.html

Rama M (2001) The consequences of doubling the minimum wage: The case of Indonesia. Ind Labor Relat Rev 54(4):864-881

Rebitzer JB, Taylor LJ (1995) The consequences of minimum wage laws some new theoretical ideas. J Public Econ 56(2):245-255

Saget C (2001) Poverty reduction and decent work in developing countries: Do minimum wages help? Int Labour Rev 140(3):237-269

Stock J, Yogo M (2005) Testing for weak instruments in linear IV regression (Andrews DWK, ed.). Cambridge University Press, New York. Cambridge University Press

Strobl E, Walsh F (2003) Minimum wages and compliance : The case of Trinidad and Tobago. Open Access publications from University College Dublin 10197/184, University College Dublin

Suryahadi A, Widyanti W, Perwira D, Sumarto S (2001) The impact of minimum wage policy on wages and employment in developing countries: The case of Indonesia. Economics Study Area Working Papers 38, East-West Center, Economics Study Area

Te Velde D, Morrissey O (2004) Foreign direct investment, skills and wage inequality in East Asia. J Asia Pac Econ 9(3):348-369

Welch F (1974) Minimum wage legislation in the United States. Econ Inquiry 12(3):285-318 